\title{
Comparison of sequential extraction techniques and fractional composition of humic substances in chernozems and phaeozems of Poland - A review
}

\author{
Michał Dudek*, Beata Łabaz, Cezary Kabała \\ Wroclaw University of Environmental and Life Sciences, Institute of Soil Sciences and Environmental Protection, Grunwaldzka 53 St., 50-375 \\ Wroclaw, Poland \\ * MSc M. Dudek, michal.dudek@upwr.edu.pl
}

Received: 19.08.2020

Accepted: 07.01.2021

Associated editor: B. Glina

\section{Keywords}

Soil humus

Fractional composition

Alkaline extraction

Chernozems

Phaeozems

\begin{abstract}
Studies on organic matter have always been an important part of soil environment characterization. However, an extraction of humic substances from the organo-mineral complexes is difficult and requires special procedures. Sodium hydroxide, sodium pyrophosphate and sulfuric acids are among the basic extractants. However, its application in various order, combinations and concentrations arises question on the comparability of the results obtained from various methods. The aim of the review was to compare the major fractionation procedures according to Tiurin, Kononowa/Belczikowa, Boratyński/Wilk, and Duchaufour/Jacquin, and the composition of soil humus as investigated by these methods, using the published data for chernozemic soils from various regions of Poland. The comparison confirmed, that these major fractionation procedures are hardly comparable in chemical terms due to differences in extraction environment. However, taking into account the declared binding strength of extracted humus fractions to the mineral soil compounds, the methods of Tiurin and Boratyński/Wilk gave the most compatible results. In general, all applied methods indicated a predominance of the humus fractions weakly and more strongly bound to nonsilicate soil compounds (apart from the high contribution of humins/non-extractable residuum). Considering all multistage and long lasting procedures applying different reagents in various concentration, the best results can be achieved with method of Tiurin. At the same time authors suggest that more advanced studies concerning composition, structure or other properties of extracted humic substances using the non-invasive procedures need to be carried out
\end{abstract}

\section{Introduction}

Soil organic matter (SOM) is one of the most essential components of soil, due to its beneficial effects on the physical, chemical and biological soil properties (Swift, 1996; Drewnik, 2006; Gonet et al., 2007; Weber et al., 2018). SOM properties may significantly differ due to specific pedogenesis and habitat conditions (Dziadowiec, 1992; Stevenson, 1994; Kwiatkowska-Malina, 2018). Therefore, a qualitative and quantitative analysis of humic substances (HS), the crucial part of SOM, is an important tool providing valid information about the stability of the ecosystem, dominant soil processes, and soil trophic status (Schnitzer, 1978; Hayes and Swift, 1990).

The importance of humus has been deducted as early as in the late 18th century and since then, the attempts of extraction, description and chemical characterization of HS have been made (Kabała, 2015). The soil treatment with acid or alkaline solutions gained widespread popularity and led to the isolation of many organic compounds, to which the structure and function in soil environment were assigned (Kononowa, 1968). So many humic substances have been isolated and named as separate compounds by the end of the 19th century that it led to a general criticism for chemical extraction as creating "analytical artifacts" (Waksman, 1925; Stevenson, 1994). The debates on the extraction and fractionation of HS have continue until present and still concentrate on the question of how the materials obtained by chemical extraction represent true structure and biological function of organic matter (Kleber and Johnson, 2010; Lehman and Kleber, 2015; Olk et al., 2019). However, it does not change a commonly accepted statement that there is no better alternative than sodium hydroxide solution for the separation of the humic substances from soil (Schnitzer and Monreal, 2011; Ohno et al., 2019), despite an increasing suitability of non-destructive quantitative analysis (Chodak, 2008; Strouhalova et al., 2019; Wells, 2019). However, even scientist who support the classical alkaline extractions in SOM studies, faced a problem of inconsisten- 
cy between extraction procedures and possible incomparability of their results (Andrzejewski, 1963; Mucha, 1961).

In Poland, as in the other countries, several methods of chemical fractionation of soil humus have been applied (Dziadowiec and Gonet, 1999; Swift, 1996). Therefore, it becomes an important question, how consistent is the current knowledge about humus fractions in particular soil types if researchers used various fractionation techniques. This issue does not confine exclusively to the contribution of identified fractions, but also to the conclusions on how the composition of humus influences the soil functions.

An analysis of the fractional composition of humus has been done in Poland in various soil types (e.g. Uggla et al., 1978; Skłodowski, 1986; Gałka and Łabaz, 2013; Jamroz et al., 2014; Wasak and Drewnik, 2016); however it has focused in majority on chernozemic soils: chernozems and black earths, and less frequently on chernozemic/humic rendzinas. Chernozemic soils are featured by the abundance of a high quality humus, which enhances soil fertility and crop yields (e.g. Borowiec and Wybieralska, 1969; Turski, 1971; Licznar and Drozd, 1985; Licznar et al., 2004). Therefore, the mentioned group of soils seems to be one of the bests objects for comparison purposes.

The aim of the review was (a) to compare the humus sequential fractionation procedures most commonly applied in Poland and (b) to compare their quantitative results for chernozemic soils (chernozems and black earths) from various regions of Poland, based on the data available in published papers.

\section{Methodology of comparative analysis}

The analysis in this study based on Polish papers concerning sequential humus fractionation published since the end of World War II. The comparison includes the methods according to Tiurin (T method), Kononowa and Belczikowa (K-B method), Boratyński and Wilk (B-W method), Duchaufour and Jacquin (DJ method) (Tab. 1), collected in the laboratory guidebook for soil organic matter studies (Dziadowiec and Gonet, 1999). The fractionation technique according to Ponomarieva and Plotnikova (1980) has not been included due to the lack of papers presenting the results of this method from Polish chernozemic soils. Also the popular procedure of Schnitzer (1978) and standard IHSS extraction (Swift, 1996) have been omitted, as these methods are not classical, sequential fractionations of whole soil humus, but only extract a selected single fraction of humic substances for further separation, purification and structural analyses of involved humic and fulvic acid. These single extractions, although are commonly used to characterize the composition of humic substances, do not cover a significant portion of poorly-extractable organic substances, involved in "humus" definition most commonly applied in Poland (Gonet et al., 2015). Thus, although the simplified single extractions have received increasing popularity in recent decades (Drozd et al., 2009; Drąg et al., 2010; Kondratowicz-Maciejewska et al., 2012; Ćwieląg-Piasecka et al., 2018; Weber et al., 2020) are, from definition, incomparable with sequential extraction and provide different information about soil humus (Swift, 1996).
The first step of analysis was to classify the different fractions mentioned in particular procedures into few "generalized" fractions, taking into account similarity of chemicals used for their extraction and similarity of a declared (by authors) strength of binding to mineral soil compounds. Four extractable fractions and the "fraction" of non-extractable residuum were distinguished:

I. Low-molecular humic substances (HS), mostly mobile fulvic acids (CF), extracted with diluted acid solutions,

II. 'Mobile' HS, weakly bound to non-silicate compounds, extracted by single application of sodium hydroxide $(\mathrm{NaOH})$ or sodium pyrophosphate $\left(\mathrm{Na}_{4} \mathrm{P}_{2} \mathrm{O}_{7}\right)$,

III. HS more strongly bound to non-silicate compounds and calcium ions, extracted with $\mathrm{NaOH}$ after decalcification, or with a mixture of $\mathrm{NaOH}$ and $\mathrm{Na}_{4} \mathrm{P}_{2} \mathrm{O}_{7}$,

IV. Stable HS bound mostly to silicate minerals, extracted with $\mathrm{NaOH}$ after acidic hydrolysis (or alternately with hydrolysis),

V. Non-extractable residuum, sometimes identified as "humins".

All five "fractions" were distinguished in the Tiurin method only; whereas, the first or the fourth-fifth fractions were omitted or combined by other procedures (Tab. 1). Simultaneously, the fractions II-IV were further divided into humic $(\mathrm{CH})$ and fulvic (CF) acids to determine $\mathrm{CH}$ :CF ratio in each of the extracted fraction. The procedures under analysis listed the fractions in different order and applied different nomenclature (fraction names). To make the comparison clear and understandable, the original fraction symbols and names are not used in this paper in favor of standardized symbols and fraction names, as listed in table 1.

The reported data were separately analysed for chernozems ("dry" Chernozems and Phaeozems) and black earths ("moist"/ gleyed Chernozems and Phaeozems) using their original classification (provided by authors), even if their modern classification would differ, in particular in case of soils developed from loess (Drozd et al., 2007; Łabaz et al., 2018). The terms „chernozemic soils”, „chernozems” and „black earths”, written in lowercase, refers to Polish Soil Classification (Systematyka Gleb Polski, 2019), while the „Chernozems” and „Phaeozems” are the Reference Soil Groups in terms of WRB Classification (IUSS Working Group WRB, 2015). The results of humus fractionation in chernozems (7 soil profiles) are available from southern Poland only, i.e. Lublin Upland, Miechów Upland and Głubczyce Plateau (Drozd, 1973; Gliński and Turski, 1965; Licznar, 1985; Licznar et al., 1993; Licznar and Drozd, 1985; Turski, 1964, 1971; Wilk and Nowak, 1977). The data for black earths (14 soil profiles) are available from various parts of Poland, but mostly from the central and western ones (Borowiec and Wybieralska, 1969; Licznar et al., 2004; Łabaz, 2007, 2010; Łabaz et al., 2008; Łakomiec and Kozakiewicz, 1970). Approximated locations of soil pits from reviewed literature are presented on Fig. 1. The most frequently observed ranges of the fractions extracted in the topsoil layers are summarized in tables 2 and 3. To unify the data and to allow their comparison, all results are presented as a percentage of the carbon in a particular fraction to the total soil organic carbon content considered as $100 \%$ (measured typically using the Tiurin method). 
Table 1

Comparison of major fractions of the humic substances extracted using four most common methods

\begin{tabular}{|c|c|c|c|c|c|c|c|c|}
\hline \multirow{2}{*}{$\begin{array}{l}\text { Fraction } \\
\text { I } \\
\text { Low-molecular } \\
\text { HS, mostly } \\
\text { mobile FA }\end{array}$} & \multicolumn{3}{|c|}{ Tiurin (1951) method } & \multicolumn{3}{|c|}{ Kononowa and Belczikowa (1961) method } & \multirow{2}{*}{$\begin{array}{l}\text { Boratyński } \\
\text { and Wilk } \\
\text { (1963) method } \\
-\end{array}$} & \multirow{2}{*}{$\begin{array}{l}\begin{array}{l}\text { Duchaufour } \\
\text { and Jacquin } \\
\text { (1963) method }\end{array} \\
-\end{array}$} \\
\hline & $\begin{array}{l}0.25 \mathrm{M} \mathrm{H}_{2} \mathrm{SO}_{4} \\
(\mathrm{x} 1-3)\end{array}$ & - & - & $\begin{array}{l}0.05 \mathrm{M} \mathrm{H}_{2} \mathrm{SO}_{4} \\
\text { (x1) }\end{array}$ & - & - & & \\
\hline $\begin{array}{l}\text { II } \\
\text { Mobile HS } \\
\text { bound to } \\
\text { non-silicate } \\
\text { minerals }\end{array}$ & - & $\begin{array}{l}0.1 \mathrm{M} \mathrm{NaOH} \\
\text { (x1) }\end{array}$ & - & - & $\begin{array}{l}0.1 \mathrm{M} \mathrm{NaOH} \\
\text { (x1) }\end{array}$ & - & $\begin{array}{l}0.1 \mathrm{M} \mathrm{Na}_{2} \mathrm{P}_{2} \mathrm{O}_{7} \\
(\mathrm{x} 3)\end{array}$ & $\begin{array}{l}0.1 \mathrm{M} \mathrm{Na}_{4} \mathrm{P}_{2} \mathrm{O}_{7} \\
\text { at } \mathrm{pH} 7.0+ \\
\mathrm{Na}_{2} \mathrm{SO}_{4} \\
\text { (in light } \\
\text { and heavy } \\
\text { fractions) }\end{array}$ \\
\hline $\begin{array}{l}\text { III } \\
\text { HS more } \\
\text { strongly bound } \\
\text { to non-silicate } \\
\text { minerals }\end{array}$ & - & - & $\begin{array}{l}\text { after } \\
\text { decalcination } \\
0.1 \mathrm{M} \mathrm{NaOH} \\
\text { (exhaustible) }\end{array}$ & - & - & $\begin{array}{l}0.1 \mathrm{M} \mathrm{Na}_{2} \mathrm{P}_{2} \mathrm{O}_{7} \\
+0.1 \mathrm{M} \mathrm{NaOH} \\
(\mathrm{x} 1)\end{array}$ & $\begin{array}{l}0.1 \mathrm{M} \mathrm{NaOH} \\
\text { (x3) }\end{array}$ & $\begin{array}{l}0.1 \mathrm{M} \mathrm{Na}_{4} \mathrm{P}_{2} \mathrm{O}_{7} \\
\text { at } \mathrm{pH} 9.8 \\
\text { (in light } \\
\text { and heavy } \\
\text { fractions) } \\
+0.1 \mathrm{M} \mathrm{NaOH} \\
\text { (in heavy } \\
\text { fraction only) }\end{array}$ \\
\hline $\begin{array}{l}\text { IV } \\
\text { Stable HS } \\
\text { bound } \\
\text { to silicate } \\
\text { minerals }\end{array}$ & - & - & $\begin{array}{l}0.1 \mathrm{M} \mathrm{H}_{2} \mathrm{SO}_{4} \\
+0.1 \mathrm{M} \mathrm{NaOH} \\
\text { (repeatedly) }\end{array}$ & residuum & & & $\begin{array}{l}0.5 \mathrm{M} \mathrm{H}_{2} \mathrm{SO}_{4} \\
\text { (hydrolysis) } \\
+0.1 \mathrm{M} \mathrm{NaOH} \\
\text { (exhaustible) }\end{array}$ & $\begin{array}{l}\text { sum } \\
\text { of residuum } \\
\text { of the light } \\
\text { fraction } \\
\text { and the }\end{array}$ \\
\hline $\begin{array}{l}\text { V } \\
\text { Non-extractable } \\
\text { residuum }\end{array}$ & - & - & residuum & & & & residuum & $\begin{array}{l}\text { "humins" } \\
\text { of the heavy } \\
\text { fraction }\end{array}$ \\
\hline
\end{tabular}

Explanation: HS - humic substances, FA - fulvic acids OC - organic compounds, (x1) - single extraction, (x1-3) - from one to three extractions. Phase of bitumin extraction was not included in the table.

Fig. 1. Location of soils considered in review. Explanation: black sections - Chernozems, gray sections - Phaeozems. Geographical localizations of soils under study (according to authors in Tab. 2 and Tab. 3): PY - Pyrzyce Plain, ŁA - Łagów Lake Distric, KU - Kuyavian Upland, BA - Barycz Valley, WR - Wrocław Plain, KL - Kłodzko Basin, GL - Głubczyce Plateu, PO - Proszowice Plateu, L-R - Lublin Upland/Hrubieszów Basin

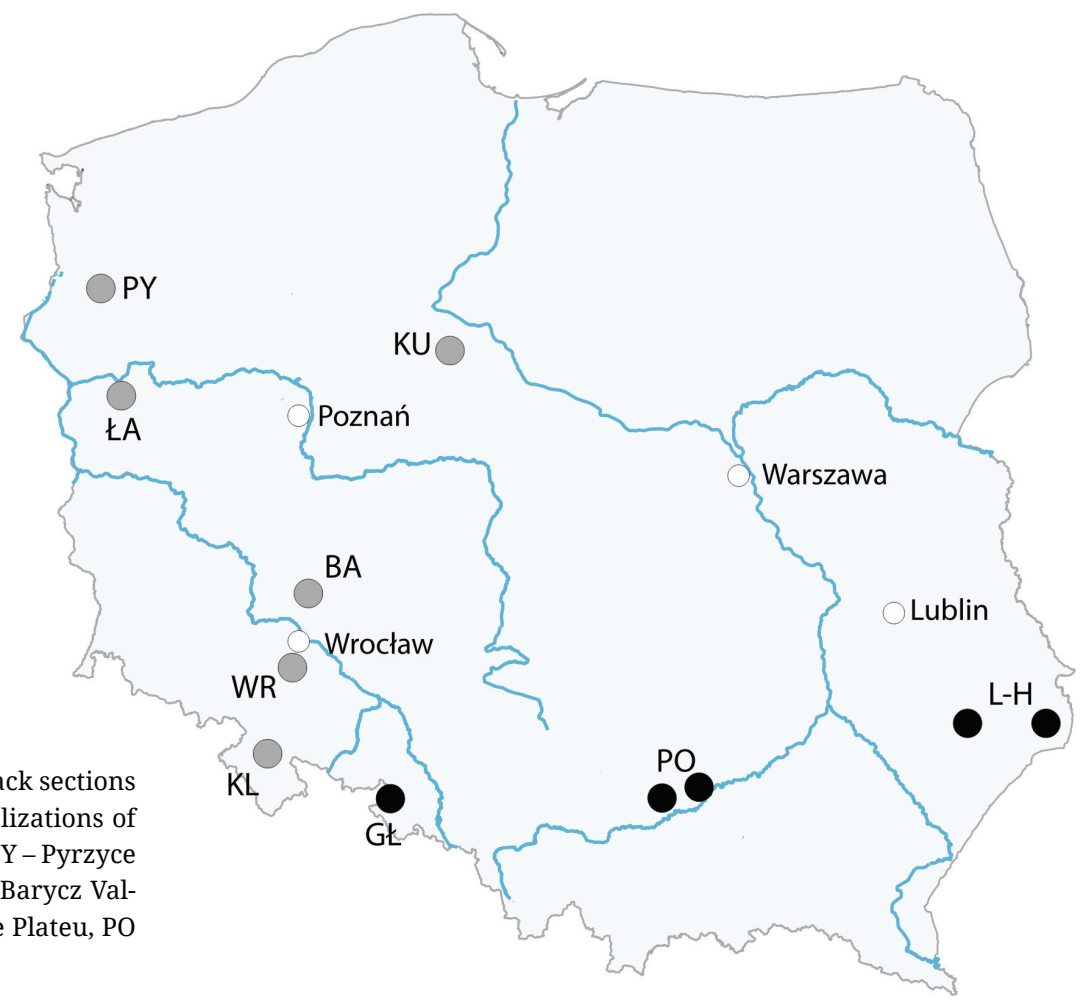


Table 2

Distribution of humus fractions extracted from topsoil layer $(0-30 \mathrm{~cm})$ of chernozems

\begin{tabular}{|c|c|c|c|c|c|c|c|c|}
\hline $\begin{array}{l}\text { Method of } \\
\text { extraction }\end{array}$ & Fraction & $\Sigma \mathrm{CH}-\mathrm{CF}$ & $\mathrm{CH}$ & $\mathrm{CF}$ & $\mathrm{CH}: \mathrm{CF}$ & $\begin{array}{l}\text { Soil types acc. to } \\
\text { references }\end{array}$ & Location & References \\
\hline \multirow[t]{8}{*}{ Tiurin } & I & - & - & 1.2 & \multirow[t]{5}{*}{1.4} & \multirow{5}{*}{$\begin{array}{l}\text { non-eroded } \\
\text { chernozem }\end{array}$} & \multirow[t]{5}{*}{ Lublin Upland } & \multirow{5}{*}{$\begin{array}{l}\text { Turski (1964) } \\
\text { Turski (1971) }\end{array}$} \\
\hline & II & 12.3 & 5.0 & 7.3 & & & & \\
\hline & III & 18.3 & 14.4 & 3.9 & & & & \\
\hline & IV & 12.4 & 6.2 & 6.2 & & & & \\
\hline & V & 43.3 & - & - & & & & \\
\hline & II & - & $5.0-5.9$ & - & \multirow[t]{3}{*}{-} & \multirow{3}{*}{$\begin{array}{l}\text { degraded } \\
\text { chernozem }\end{array}$} & \multirow[t]{3}{*}{ Lublin Upland } & \multirow{3}{*}{$\begin{array}{l}\text { Gliński } \\
\text { and Turski (1965) }\end{array}$} \\
\hline & III & - & $11.8-22.5$ & - & & & & \\
\hline & IV & - & $4.3-8.4$ & - & & & & \\
\hline \multirow{12}{*}{$\begin{array}{l}\text { Kononowa } \\
\text { and } \\
\text { Belczikowa }\end{array}$} & I & - & - & $3.3-4.1$ & \multirow[t]{4}{*}{1.2} & \multirow{4}{*}{$\begin{array}{l}\text { degraded } \\
\text { forest-steppe } \\
\text { chernozem }\end{array}$} & \multirow[t]{4}{*}{ Głubczyce Plateu } & \multirow{4}{*}{$\begin{array}{l}\text { Licznar } \\
\text { and Drozd (1985) }\end{array}$} \\
\hline & II & $17.5-36.5$ & $8.1-23.1$ & $9.4-13.4$ & & & & \\
\hline & III & $6.8-15.4$ & $4.0-13.1$ & $2.3-4.2$ & & & & \\
\hline & $\mathrm{IV}+\mathrm{V}$ & $52.4-63.7$ & - & - & & & & \\
\hline & I & - & - & 3.3 & \multirow[t]{4}{*}{1.4} & \multirow{4}{*}{$\begin{array}{l}\text { degraded } \\
\text { forest-steppe } \\
\text { chernozem }\end{array}$} & \multirow[t]{4}{*}{ Głubczyce Plateu } & \multirow{4}{*}{$\begin{array}{l}\text { Drozd } \\
\text { and Licznar } \\
(1985)\end{array}$} \\
\hline & II & 36.5 & 23.1 & 13.4 & & & & \\
\hline & III & 6.8 & 4.0 & 2.8 & & & & \\
\hline & $\mathrm{IV}+\mathrm{V}$ & 53.3 & - & - & & & & \\
\hline & I & - & - & 4.2 & \multirow[t]{4}{*}{0.9} & \multirow{4}{*}{$\begin{array}{l}\text { humus deluvial } \\
\text { chernozemic soil }\end{array}$} & \multirow[t]{4}{*}{ Głubczyce Plateu } & \multirow{4}{*}{$\begin{array}{l}\text { Licznar et al. } \\
\text { (1993) }\end{array}$} \\
\hline & II & 20.0 & 10.9 & 9.1 & & & & \\
\hline & III & 20.3 & 18.3 & 2.0 & & & & \\
\hline & $\mathrm{IV}+\mathrm{V}$ & 55.5 & - & - & & & & \\
\hline \multirow{16}{*}{$\begin{array}{l}\text { Boratyński } \\
\text { and Wilk }\end{array}$} & II & 14.7 & 9.0 & 5.7 & 1.9 & arable degraded & Hrubieszów & Drozd (1973) \\
\hline & III & 26.5 & 16.5 & 10.2 & & chernozem & Basin & \\
\hline & IV & 12.7 & 10.5 & 2.2 & & & & \\
\hline & V & 42.5 & - & - & & & & \\
\hline & II & 18.7 & 11.8 & 6.9 & 1.8 & degraded & & \\
\hline & III & 25.1 & 14.3 & 10.9 & & chernozem & & \\
\hline & IV & 7.7 & 5.4 & 2.4 & & (g1аssianu) & & \\
\hline & V & 44.5 & - & - & & & & \\
\hline & II & 21.8 & 11.6 & 10.2 & 0.8 & degraded & & \\
\hline & III & 26.6 & 12.8 & 13.0 & & chernozem (forest) & & \\
\hline & IV & 7.3 & 5.5 & 1.8 & & & & \\
\hline & $\mathrm{V}$ & 41.5 & - & - & & & & \\
\hline & II & 12.2 & 2.9 & 9.3 & 0.8 & degraded & Proszowice & Wilk and Nowak \\
\hline & III & 30.5 & 12.9 & 17.7 & & chernozem & Plateu & (1977) \\
\hline & IV & 14.0 & 6.1 & 7.9 & & & & \\
\hline & V & 43.4 & - & - & & & & \\
\hline Duchaufour & II & 12.1 & 2.9 & 9.2 & - & degraded & Proszowice & Kuźnicki \\
\hline and Jacquin & III & 15.8 & 12.0 & 3.8 & & chernozem & Plateu & and Sklodowski \\
\hline & $\mathrm{IV}+\mathrm{V}$ & 60.7 & - & - & & & & (1968) \\
\hline & II & 13.5 & 2.9 & 10.6 & - & degraded & Proszowice & Kuźnicki \\
\hline & III & 14.4 & 8.9 & 5.5 & & chernozem & Plateu & and Sklodowski \\
\hline & $\mathrm{IV}+\mathrm{V}$ & 65.9 & - & - & & & & $(19 / 3)$ \\
\hline
\end{tabular}


Table 3

Distribution of humus fractions extracted from topsoil layer $(0-30 \mathrm{~cm})$ of black earths

\begin{tabular}{|c|c|c|c|c|c|c|c|c|}
\hline $\begin{array}{l}\text { Method of } \\
\text { extraction }\end{array}$ & Fraction & $\Sigma \mathrm{CH}-\mathrm{CF}$ & $\mathrm{CH}$ & $\mathrm{CF}$ & $\mathrm{CH}: \mathrm{CF}$ & $\begin{array}{l}\text { Soil types acc. } \\
\text { to references }\end{array}$ & Location & References \\
\hline \multirow[t]{32}{*}{ Tiurin } & II & 21.3 & 13.4 & 7.9 & \multirow[t]{2}{*}{-} & \multirow{2}{*}{$\begin{array}{l}\text { black earth } \\
\text { (silty texture) }\end{array}$} & \multirow{2}{*}{$\begin{array}{l}\text { Łowicz-Błonie } \\
\text { Plain }\end{array}$} & \multirow{2}{*}{$\begin{array}{l}\text { Łakomiec and } \\
\text { Kozakiewicz (1970) }\end{array}$} \\
\hline & III & 40.6 & 29.8 & 10.8 & & & & \\
\hline & I & - & - & $2.7-3.1$ & \multirow[t]{5}{*}{$1.0-1.9$} & \multirow{5}{*}{$\begin{array}{l}\text { black earth } \\
\text { Calcic Gleyic } \\
\text { Chernozems } \\
\text { (loamy texture) }\end{array}$} & \multirow[t]{15}{*}{ Wrocław Plain } & \multirow[t]{15}{*}{ Łabaz (2007) } \\
\hline & II & $4.0-4.1$ & $0.7-0.9$ & $3.2-3.3$ & & & & \\
\hline & III & $43.8-64.7$ & $32.3-39.2$ & $11.5-25.5$ & & & & \\
\hline & IV & $4.8-8.1$ & $2.4-6.8$ & $1.5-2.5$ & & & & \\
\hline & V & $23.4-41.3$ & - & - & & & & \\
\hline & I & - & - & $2.9-3.4$ & \multirow[t]{5}{*}{$1.4-1.9$} & \multirow{5}{*}{$\begin{array}{l}\text { black earth } \\
\text { Gleyic Pachic } \\
\text { Phaeozems } \\
\text { (silty texture) }\end{array}$} & & \\
\hline & II & $11.0-12.3$ & $4.9-6.2$ & 6.2 & & & & \\
\hline & III & $37.4-48.7$ & $26.6-36.6$ & $10.5-12.0$ & & & & \\
\hline & IV & $3.0-3.8$ & $1.7-2.5$ & $0.7-2.0$ & & & & \\
\hline & V & $34.5-43.2$ & - & - & & & & \\
\hline & I & - & - & $4.7-5.7$ & \multirow[t]{5}{*}{$1.0-1.1$} & \multirow{5}{*}{$\begin{array}{l}\text { degraded } \\
\text { black earth } \\
\text { (silty texture) }\end{array}$} & & \\
\hline & II & $32.2-33.0$ & $17.8-18.9$ & $14.1-14.4$ & & & & \\
\hline & III & $14.4-15.8$ & $5.2-8.9$ & $6.9-9.1$ & & & & \\
\hline & IV & $16.6-17.0$ & $6.0-8.3$ & $8.0-11.1$ & & & & \\
\hline & $\mathrm{V}$ & $30.4-30.5$ & - & - & & & & \\
\hline & I & - & - & $1.3-5.0$ & \multirow[t]{5}{*}{$0.7-1.2$} & \multirow{5}{*}{$\begin{array}{l}\text { degraded } \\
\text { black earth } \\
\text { (sandy texture) }\end{array}$} & \multirow[t]{5}{*}{ Barycz Valley } & \multirow[t]{5}{*}{ Łabaz et al. (2008) } \\
\hline & II & $22.7-43.4$ & $8.6-26.2$ & $14.1-20.0$ & & & & \\
\hline & III & $1.3-5.9$ & - & - & & & & \\
\hline & IV & $10.6-22.0$ & $6.9-7.4$ & $3.7-14.6$ & & & & \\
\hline & V & 45.1-55.8 & - & - & & & & \\
\hline & I & - & - & 4.3 & - & black earth & Kłodzko Basin & Łabaz (2010) \\
\hline & II & - & 5.0 & - & & Gleyic Chernozem & & \\
\hline & III & - & 21.2 & - & & (clayey texture) & & \\
\hline & IV & 5.0 & 3.4 & 1.6 & & & & \\
\hline & V & 47.9 & - & - & & & & \\
\hline & I & - & - & $3.9-5.9$ & - & degraded & & \\
\hline & II & - & $2.9-5.0$ & - & & black earth & & \\
\hline & III & - & $21.5-24.1$ & - & & Gleyic Phaeozems & & \\
\hline & IV & $5.0-5.3$ & $3.2-3.6$ & $1.4-2.1$ & & (crayey texture) & & \\
\hline & V & $40.0-50.3$ & - & - & & & & \\
\hline Boratynski & II & 10.8 & 5.0 & 5.8 & 0.9 & black earths & Pyrzyce Plain & Borowiec \\
\hline and Wilk & III & 19.7 & 11.1 & 8.6 & & (sandy texture) & & and Wybieralska \\
\hline & IV & 14.2 & 8.1 & 6.1 & & & & (1969) \\
\hline & V & 36.7 & - & - & & & & \\
\hline & II & $23.9-26.0$ & $11.9-12.7$ & $12.0-13.3$ & 0.9 & forest & & \\
\hline & III & $16.8-29.8$ & $9.1-12.9$ & $7.7-16.9$ & & black earths & & \\
\hline & IV & $6.6-8.4$ & $3.3-3.5$ & $3.1-5.1$ & & (silty texture) & & \\
\hline & V & $27.9-28.5$ & - & - & & & & \\
\hline & II & $15.5-51.5$ & $8.8-20.5$ & $6.7-31.0$ & $0.7-1.3$ & arable & & \\
\hline & III & $9.9-19.6$ & $2.4-9.3$ & $0.8-3.1$ & & black earths & & \\
\hline & IV & $6.1-13.2$ & $3.8-8.0$ & $2.3-5.3$ & & (silty texture) & & \\
\hline & $\mathrm{V}$ & $7.0-53.9$ & - & - & & & & \\
\hline & II & 15.9 & 7.1 & 8.8 & 1.1 & black earth & Łagów Lake & Wilk and Nowak \\
\hline & III & 22.7 & 11.1 & 11.6 & & (sandy texture) & District & (1977) \\
\hline & IV & 13.4 & 7.0 & 6.4 & & & & \\
\hline & V & 47.6 & - & - & & & & \\
\hline & II & 11.9 & 4.1 & 7.8 & 0.6 & black earths & Wrocław Plain & \\
\hline & III & 13.5 & 4.5 & 9.0 & & (silty texture) & & \\
\hline & IV & 22.0 & 10.8 & 11.2 & & & & \\
\hline & $\mathrm{V}$ & 49.4 & - & - & & & & \\
\hline Duchaufour & II & 13.5 & 2.9 & 10.6 & - & black earths & Kuyavian Upland & Kuźnicki \\
\hline and Jacquin & III & 14.4 & 8.9 & 5.5 & & (loamy texture) & & and Skłodowski \\
\hline & $\mathrm{IV}+\mathrm{V}$ & 65.9 & - & - & & & & (1968) \\
\hline
\end{tabular}




\section{Comparison of methods of humus fractionation applied} in Poland

Among the procedures of humus fractionation applied in Poland, the method of Tiurin (1951) undoubtedly gained the highest popularity. Originally it was preferred due to numerous studies performed in the USSR on various soil types, which gave Polish scientists access to a comparison base (Musierowicz et al., 1960). Tiurin method (T method) allows separating (after prior removal of bitumens): (i) the most mobile fraction of HS, extracted with dilute sulfuric acid, (ii) low-molecular compounds bound to calcium and non-silicate $\mathrm{R}_{2} \mathrm{O}_{3}$ forms (originally called „humic compounds bound to $\mathrm{Ca}$ and mobile, non-silicate forms of $\mathrm{R}_{2} \mathrm{O}_{3}$ "), (iii) humus compounds bound more heavily to silicates (originally called „humic compounds bound to the stable silicate forms of $\mathrm{R}_{2} \mathrm{O}_{3}$ ”) and (iv) post-extraction residue composed of the non-humified organic materials (Dziadowiec and Gonet, 1999). Frequently highlighted advantage of this method is high efficiency of the extraction (defined as the percentage of extracted carbon do total organic carbon) and the possibility to determine the amount of humic components strongly bound to mineral phase (Kozakiewicz, 1966; Kleszczycki et al., 1967; Wilk, 1971). However, T method is time-consuming and requires a lot of effort during the process of analysis (Kononowa, 1968). Also the sample decalcination before $\mathrm{NaOH}$ application was criticized (Kuźnicki and Skłodowski, 1968; Aleksandrowa, 1980). The shortcomings of the T method encouraged scientist to simplify the fractionation procedure and to implement sodium pyrophosphate. One of the functions of this reagent was to improve decalcination step, i.e. to replace acids in the calcium removal from humus complexes (Boratyński and Wilk, 1961; Kononowa and Belczikowa, 1961; Kowaliński et al., 1973). In particular, the method of Kononowa and Belczikowa (hereafter K-B method) was proposed as a quick and effective procedure, significantly simplified compared to T method. The K-B method distinguished three fractions: (i) low-molecular, mobile organic substances (extracted with weak sulfuric acid), (ii) stable HS bound to silicate minerals (extracted with $\mathrm{NaOH}$ without decalcification), and (iii) HS more strongly bound to calcium and silicate minerals (extracted using the mixture of $\mathrm{NaOH}$ and sodium pyrophosphate) (Table 1). Despite its simplicity, the method got relatively little interest in Poland, mostly due to its low extraction efficiency compared to Tiurin method that limited its applicability in soils poorer in humus (Wilk, 1963; Kozakiewicz, 1966; Kleszczycki et al., 1967). An alternative method of Boratyński and Wilk (1961; hereafter B-W method) assumed sequential extraction of three essential fractions: (i) mobile HS (extracted with sodium pyrophosphate), (ii) HS bound to non-silicate compound, and (iii) HS strongly bound to silicate minerals (Table 1). Low extraction efficiency was indicated as the most severe problem of this procedure (Kowaliński et al., 1973). Contrary to methods mentioned above, the procedure of Duchaufour and Jacquin (1963; hereafter D-J method) based primarily on the differences in a density of particular organic substances. The humic substances were separated in heavy liquid (bromoform) in an initial phase of the fractionation (Kuźnicki and Skłodowski, 1968; Gałka and Łabaz, 2014). In the next steps, the method used a sodium pyrophos- phate solution buffered, subsequently, to the neutral and highly alkaline reaction (Table 1). Both the separation of HS fractions based on their density and the further extraction of HS using the sodium pyrophosphate in combinations with acids or bases made the D-J method technically incomparable with all the procedures mentioned above (Wilk, 1971; Wilk and Nowak, 1977).

\section{Results of humus fractionation in chernozemic soils using various methods}

\subsection{Low-molecular organic compounds of the highest mobility - Fraction I}

HS extracted in the first phase of fractionation (after removal of bitumins) using weak sulphuric acid (0.05-0.25 $\mathrm{M} \mathrm{H}_{2} \mathrm{SO}_{4}$ ) are considered the most mobile fulvic acids; however, many non-specific organic compounds, easily soluble in weak acid solution, including the so-called dissolved organic carbon, are involved in this fraction. Fraction I is separated only in the T and $\mathrm{K}-\mathrm{B}$ methods (Table 1) and generally is added to the sum of fulvic acids (Table 2). In general, the fraction had the lowest contribution in the soil humus, in a range of $1.2-4.2 \%$ of SOC in chernozems. The K-B method extracted noticeably higher amounts of fraction I than T method (Fig. 2). Mean values of fraction I (extracted using $\mathrm{T}$ procedure) were lower in chernozems than in black earths (Fig. 2 and 3), although the range of values was wider in black earths (Table 3 ) that resulted from more variable soil properties, the soil texture in particular. Somewhat higher percentage (2.7-5.9\%) was reported in the silty and clayey black earths (Łabaz, 2007, 2010), even classified as 'degraded black earths', than in soils developed from sands (values between 1.3-5\%), (Łabaz, 2008).

\section{2. 'Mobile' HS weakly bound to mineral soil phase - Fraction II}

Organic compounds traditionally described as weakly bound with non-silicate forms of $\mathrm{R}_{2} \mathrm{O}_{3}$ are extracted by single extraction with $0.1 \mathrm{M} \mathrm{NaOH}$ (without decalcination) in $\mathrm{T}$ and $\mathrm{K}$ B methods or by triple extraction with sodium pyrophosphate, as in B-W (Table 1). Despite declared similar extraction power, the results obtained using various procedures varied in a broad range. In chernozems, the highest amounts of fraction II were obtained using K-B method (17.5-36.5\% of SOC) by Licznar and Drozd (1985), while the other methods yielded in noticeably lower amounts: 12.1-13.5\% using T and D-J methods (Turski, 1964, 1971; Kuźnicki and Skłodowski, 1968, 1973) and 12.2-21.8\% using B-W method (Drozd, 1973; Wilk and Nowak, 1977). The mean contribution of fraction II (Fig. 2 and 3) and the maximum content of this fraction (Table 3) in arable black earths were higher than in chernozems. Borowiec and Wybieralska (1969) reported up to $51.5 \%$ of this fraction using B-W method and Łabaz et al. (2008) reported up to $43.3 \%$ using T method. Large differences in the fraction contribution were noticed even in relatively similar soils located in the same region (Table 3 ). The values in the black earths of the Wroclaw Plain varied from ca. $4 \%$, through $12 \%$, 
Fig. 2. Range and mean values of humus fractions extracted in chernozems

Numbers (symbols) of fractions are explained in Table 1
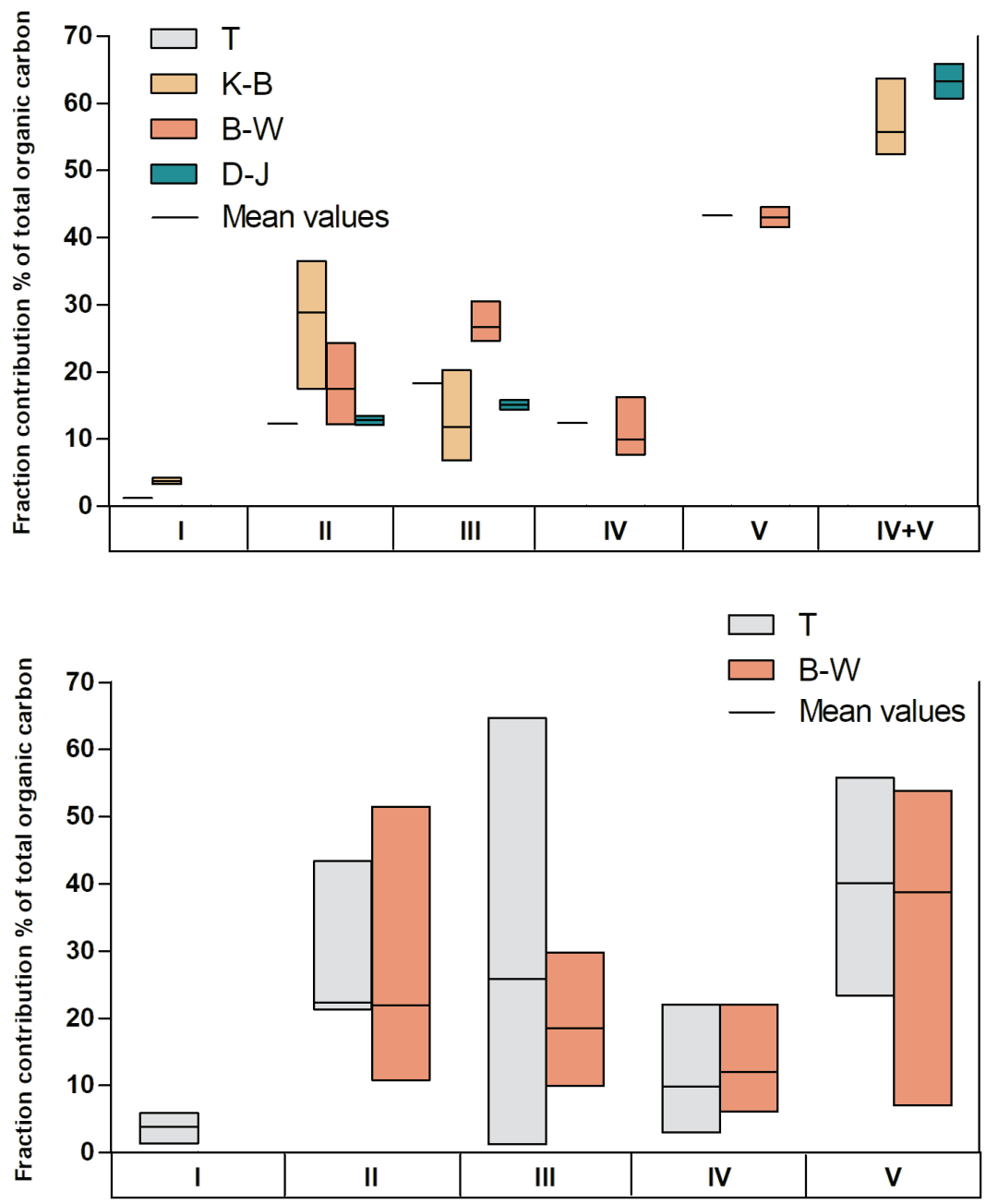

Fig. 3. Range and mean values of humus fractions extracted in black earths

Numbers (symbols) of fractions are explained in Table 1
7-20\%, respectively) (Table 2). In the 'typical' black earths the contribution of fraction III reached even 37-65\% (Łabaz, 2007; Łakomiec and Kozakiewicz, 1970), whereas in the 'degraded' black earths did not exceed 16\% (Łabaz, 2007). If in chernozems the $\mathrm{T}$ procedure extracted less $\mathrm{HS}$ than the B-W one, in black earths efficiency of the methods is opposite in favour of the $\mathrm{T}$ procedure (Fig. 2 and 3). Regardless soil type and applied method, the majority of chernozemic soils was featured with noticeably higher content of $\mathrm{CH}$ than $\mathrm{CF}$ in the fraction III.

\subsection{Stable HS strongly bound to silicate minerals - Fraction IV}

The fraction is extracted with $0.1 \mathrm{M} \mathrm{NaOH}$ after prior acidic hydrolysis (in B-W method) or with $0.1 \mathrm{M} \mathrm{NaOH}$ alternated with hydrolysis (in T method), and typically has exhaustible character (Table 1). Fraction IV consists of HS considered to be strongly bound to silicate mineral phase of soil, mostly the clay minerals. In case of chernozems, the obtained results are relatively low (8-14\%) regardless the geographical location of soils. In black earths, authors described much wider range of contribution (3-33\%) (Table 3); however, the mean value was similar to this in chernozems (Fig. 2 and 3). Higher amounts of fraction IV were in the 'degraded' and sand-textured black earths (11-22\%), 
compared to 'typical' and silt/loam-textured soils (Borowiec and Wybieralska, 1969; Łabaz, 2008). This observation proved that the contribution of fraction IV in some soils did not result simply from binding of the HS to silica minerals, but suggests the significant resistance of organic compounds for alkaline extractions applied in the previous phases.

\subsection{Non-extractable residue}

The term "residue" represents post-extraction residue composed of the non-humified organic materials strongly bounded with mineral phase of soils and non-extractable during previous phases. Residual fraction is not obtained separately, but is calculated as the difference of the total organic carbon content (TOC) and sum of fraction I-IV (in T and B-W methods) or I-III (in K-B and B-J methods). The contribution of residues in TOC depends mainly on humic substances described as active. In chernozems occurs $42-45 \%$ of non-extractable residues according to $\mathrm{T}$ and B-W (Turski, 1964, 1971; Drozd, 1973) or even 52-66\% in K-B and D-J procedures (Fig. 2) (Licznar and Drozd, 1985; Kuźnicki and Skłodowski, 1968, 1973; Licznar et al., 1993). In case of phaeozems variation of values were significantly higher (23-56\%) probably due to different soil properties, particularly the texture and total content of humus (Table 3). However, mean contents of fraction $\mathrm{V}$ in chernozemic soils are similar and reach up to $40 \%$ (Fig. 2; Fig 3).

\section{Discussion}

Classically, the humic substances are derived and classified based on their solubility in particular alkaline or acid reagents (Piccolo, 2002). Therefore, the fundamental problem in the organic matter studies still concerns the selection of the proper extractants to separate expected groups of organic compounds (Lehman and Kleber, 2015; Weber et al., 2020). Procedures developed by various researchers (Boratyński and Wilk, 1964; Duchaufour and Jacquin, 1963; Kononowa, 1968; Tiurin, 1951) have similar assumptions and are intended to implement stronger extraction agents in the following steps of the analysis. However, only the B-W method is a true sequential fractionation, i.e. the same soil sample in treated by subsequent chemicals, while the $\mathrm{T}$ and K-B methods base mostly or exclusively on parallel extractions from separate soil samples. The D-J method is also a sequential fractional; however, carried on two parallel samples obtained after preliminary separation of HS due to their density (Table 1). Moreover, the methods under comparison differ significantly in extracting the most mobile and most strongly bound fractions. Fraction I was separated only in T and K-B methods, while the fraction IV is distinguished from the (non-extractable) residuum in the $\mathrm{T}$ and B-W methods only (Table 1). Additionally, particular procedures apply different chemicals, different concentrations of the same chemicals, and different combinations or order of chemicals, e.g. as a single, triple, or exhaustive extraction. Thus, taking into account many fundamental differences, it should be a priori concluded that reviewed methods are incomparable in chemical terms due to applying different methodology, which must result in extracting of different portions of HS. Starting from such point of view, any comparison of the results obtained by different methods should be a priori rejected.

Alternatively, the comparison may follow the declared similarity of the extracted fractions in a strength of HS binding to mineral soil compounds, deducted after the extracting power of chemicals used under specified conditions. Hence, during the initial phase of this review, original classifications of the HS fractions and their names proposed by authors have been standardized. When applying such approach, the comparison of extraction results has revealed relative similarity of $\mathrm{T}$ and BW methods, both for chernozems and black earths. Mentioned methods indicated that approximately $40 \%$ of SOC in these soils was in phases non-extractable in course of an alkaline and alternate alkaline-acid extractions (Fig. 2 and 3). K-B and D-J procedures claims that only fractions I-III belong to active HS, thus they approximated even up to $65 \%$ of SOC in the non-extractable organic residuum, considered environmentally inactive (Kononowa, 1968). It must be stated that sum of fractions IV $+\mathrm{V}$ in the $\mathrm{T}$ and $\mathrm{K}-\mathrm{B}$ is similar, even incomparability of the procedures declared by their authors (Kononowa and Belczikowa, 1961). A dominant fraction of humus, based on the T and B-W procedures, was fraction III, i.e. HS medium strongly bound to non-silicate soil compounds (approx.. 20-30\% of SOC), but the contribution of the fraction II (i.e. mobile HS weakly bound to mineral phase) is only slightly lower. The lowest contribution ( $<5 \%$ of SOC) was noticed in the fraction I, defined as low-molecular organic compounds featured by their highest mobility in the soil environment. Surprisingly, the highest difference between results obtained using the $\mathrm{T}$ and K-B procedures was noticed in the fraction II, although both methods applied similar methodological attempt to this fraction. The results obtained according to K-B procedure indicate supremacy of the fraction II over other HS fractions and therefore differ from the results of other methods under comparison (Fig. 2).

The general conclusions presented above based on the mean results of extractions; however, a large variability of results, i.e. wide range of HS fraction contributions must be highlighted. Therefore, there is no reliable answer on the question if the reported differences in the HS contribution result from various soil texture, carbonate or humus contents, or the degradation/transformation processes, or are technical effects of different analytical procedures. Thus, based on existing published data, it is extremely difficult to conclude about similarities or differences of fractional humus composition in chernozemic soils in Poland, as soils differing in aspects under concern, were in majority analyzed using different procedures. It is highly recommended, if the humus fractionation techniques were to be continued in the future, to select and recommend one procedure as a (national) standard to achieve comparability of the results from various soils and laboratories. The published data indicate the Tiurin method to be the most frequently applied in Poland, despite its disadvantages, and probably this procedure could serve as national standard for 'classical' humus fractionation.

It should be also noted that the above mentioned 'classical' humus fractionation defines only the proportions of HS allocated to particular fractions, but does not give the information 
about the structure or chemical composition of the HS itself (Kleber and Lehmann, 2019; Myneni, 2019). Hence, the classical fractionation does not compete or replace more advanced studies concerning elemental composition, structure or other properties of extracted HS. Ongoing discussion about the nature of HS and validity of alkaline extraction, should encourage scientists to compare existing data with the results of investigations carried using the non-invasive procedures (omitting the chemical extractions) based on NIR, MIR or UV-Vis techniques (Trendel et al., 2010; Pietrzykowski and Chodak, 2014; Strouhalova et al., 2019).

\section{Conclusions}

1. Reviewed methods are incomparable in chemical terms due to applying different methodology and reagents, which must result in extracting of different portions of humic substances.

2. Despite of some minor disadvantages, original Tiurin methods seems to thoroughly characterize HS in soil, hence it should be recommended for further use.

3. More advanced studies concerning composition, structure or other properties of extracted humic substances using the non-invasive procedures need to be carried out.

\section{References}

Aleksandrowa, L.N., 1980. Soil organic compounds and their transformation processes. Nauka, Leningrad, 1-50. (in Russian)

Andrzejewski, J., 1963. Wpływ nawożenia mineralnego na zawartość związków próchnicznych w glebie. Roczniki Nauk Rolniczych 87(3), 481-496.

Boratyński, K., Wilk, K., 1961. Skład frakcji próchnicy w niektórych madach okolic Wrocławia. Roczniki Gleboznawcze - Soil Science Annual 10 (suppl.), 645-647. (in Polish)

Boratyński, K., Wilk, K., 1964. Boratyński and Wilk’s method of fractional analysis of humus compounds and its usability for determining humus composition in mineral soils of various agricultural utilization. Roczniki Gleboznawcze - Soil Science Annual 14(suppl.), 33-38. (in Polish)

Borowiec, S., Wybieralska, A., 1969. Zróżnicowanie składu próchnicy w zależności od typu gleb i ich użytkowania. Roczniki Gleboznawcze - Soil Science Annual 20(1), 67-79. (in Polish)

Chodak, M., 2008. Application of Near Infrared Spectroscopy for Analysis of Soils. Litter and Plant Materials. Polish Journal of Environmental Studies 17(5), 631-642.

Ćwieląg-Piasecka, I., Medyńska-Juraszek, A., Jerzykiewicz, M., Dębicka, M., Bekier, J., Jamroz, E., Kawałko, D., 2018. Humic acid and biochar as specific sorbents of pesticides. Journal of Soils and Sediments 18(8), 2692-2702. https://doi.org/ 10.1007/s11368-018-1976-5

Drąg, M., Dębska, B., Tobiasova, E., 2010. Wpływ resztek pozbiorowych żyta i ziemniaka na właściwości kwasów huminowych gleb różnych typów. Roczniki Gleboznawcze - Soil Science Annual 61(4), 51-56. (in Polish with English summary)

Drewnik, M., 2006. Właściwości stropowych poziomów próchnic gleb polskiej części Karpat. Roczniki Bieszczadzkie 14, 221-235. (in Polish with English summary)

Drozd, J., 1973. Związki próchniczne niektórych gleb na tle ich fizykochemicznych właściwości. Roczniki Gleboznawcze - Soil Science Annual 24(1), 3-55. (in Polish)
Drozd, J., Licznar, M., 1985. Niektóre właściwości kwasów huminowych gleb współczesnych i zagrzebanych terenów erodowanych. Roczniki Gleboznawcze - Soil Science Annual 36(2), 17-25. (in Polish with English summary)

Drozd, J., Licznar, M., Bekier, J., 2009. Ocena dojrzałości kompostów z odpadów komunalnych na podstawie jakości związków próchnicznych i różnych form azotu. Roczniki Gleboznawcze - Soil Science Annual 60(3), 67-74. (in Polish with English summary)

Drozd, J., Piątek, J., Łabaz, B., 2007. Właściwości gleb czarnoziemnych występujących w rejonie Kłodzka. Zeszyty Problemowe Postępów Nauk Rolniczych 520(2), 447-454. (in Polish with English summary)

Duchaufour, P., Jacquin, F., 1963. Recherche d'une methode d'extraction et de fractionnement des composes humiques controlee par electrophorese. Annales Agronomiques 14, 885-918. (in French)

Dziadowiec, H., 1992. Ekologiczna rola próchnicy glebowej. Zeszyty Problemowe Postępów Nauk Rolniczych 411, 268-282. (in Polish)

Dziadowiec, H., Gonet S., 1999. Przewodnik metodyczny do badań materii organicznej gleb. Prace Komisji Naukowych PTG 120, 1-66. (in Polish)

Gałka, B., Łabaz, B., 2013. Właściwości kwasów huminowych poziomów próchnicznych gleb leśnych Gór Stołowych. Sylwan 157(10), 780-785. https://doi.org/10.26202/sylwan.2013021 (in Polish with English summary)

Galka, B., Łabaz, B., 2014. Skład frakcyjny materii organicznej powierzchniowych poziomów próchnicznych gleb leśnych Gór Stołowych. Sylwan 158(1), 18-25. https://doi.org/10.26202/sylwan.2013016 (in Polish with English summary)

Gliński, J., Turski, J., 1965. Zależność między zawartością miedzi a składem frakcjonarnym kwasów huminowych w glebach. Roczniki Gleboznawcze - Soil Science Annual 15 (suppl.), 311-314. (in Polish)

Gonet, S., Dębska, B., Zaujec, A., Banach-Szott, M., Szombathowa, N., 2007. Wpływ gatunków drzew i warunków glebowo-klimatycznych na właściwości próchnicy gleb leśnych. [In:] Gonet, S.S., Markiewicz, M., (Eds.), Rola materii organicznej w środowisku. PTSH, Wrocław, 61-98.

Gonet, S., Smal, H., Chojnicki, J., 2015. Właściwości chemiczne gleb. [In:] Mocek, A., (Ed.), Gleboznawstwo. Wydawnictwo Naukowe PWN, Warszawa, 189-230. (in Polish)

Hayes, M.H.B., Swift, R.S., 1990. Genesis, isolation, composition and structures of soil humic substances. [In:] De Boodt, M.F. et al., (Eds.), Soil colloids and their associations in aggregates. Springer, Boston, 245305.

IUSS Working Group WRB, 2015. World Reference Base for Soil Resources 2014, Update 2015. International soil classification system for naming soil and creating legends for soil maps. Food and Agriculture Organization of the United Nations, Rome. p. 182.

Jamroz, E., Kocowicz, A., Bekier, J., Weber, J., 2014. Properties of soil organic matter in Podzols under mountain dwarf pine (Pinus mugo Turra.) and Norway spruce (Picea abies (L.) Karst.) in various stages of dieback in the East Sudety Mountains, Poland. Forest Ecology and Management 330, 261-270. https://doi.org/10.1016/ j.foreco.2014.07.020

Kabała, C., 2015. Definicja próchnicy i koncepcja form próchnicy: perspektywa międzynarodowa i polskie tradycje. Ogólnopolskie seminarium naukowe „Nauka o glebie w 200-letniej tradycji kształcenia przyrodniczego w Szkole Głównej Gospodarstwa Wiejskiego w Warszawie”. Wydawnictwo SGGW, Warszawa, 44-69. (in Polish)

Kleber, M., Johnson, M.G., 2010. Advances in understanding the molecular structure of soil organic matter: implications for interactions in the environment. Advances in agronomy. Academic Press 77-142. https://doi.org/10.1016/S0065-2113(10)06003-7

Kleber, M., Lehmann, J., 2019. Humic substances extracted by alkali are invalid proxies for the dynamics and functions of organic matter in terrestrial and aquatic ecosystems. Journal of Environmental Quality 49, 207-216. https://doi.org/10.2134/jeq2019.01.0036 
Kleszczycki, A., Kozakiewicz, A., Łakomiec, I., 1967. Porównanie metod stosowanych w badaniach próchnicy gleb mineralnych. Roczniki Gleboznawcze - Soil Science Annual 12, 229-241. (in Polish)

Kondratowicz-Maciejewska, K., Kobierski, M., Murawska, A., 2012. Wpływ rodzaju użytkowania gleb rdzawych na wybrane właściwości fizykochemiczne materii organicznej. Roczniki Gleboznawcze - Soil Science Annual 63(2), 19-24. https://doi.org/10.2478/v10239-012-0019-y (in Polish with English summary)

Kononowa, M., Belczikowa, I.P., 1961. Uskoriennyje mietody opriedielenija sostawa gumusa mineralnych poczw. Poczvov 10, 75-87. (in Russian)

Kononowa, M., 1968. Substancje organiczne gleby ich budowa, właściwości i metody badań. Wydawnictwo Rolnicze i Leśne Warszawa. (in Polish)

Kowaliński, S., Drozd, J., Licznar, M., 1973. Zmodyfikowana metoda oznaczania składu frakcyjnego próchnicy w glebach mineralnych. Roczniki Gleboznawcze - Soil Science Annual 24(1), 129-144. (in Polish with English summary)

Kozakiewicz, A., 1966. Nowe poglądy na skład próchnicy niektórych typów gleb mineralnych w świetle wyników uzyskanych zmodyfikowaną metodą Tiurina (cz. I.). Soil Science Annual - Roczniki Gleboznawcze 16(1), 113-130. (in Polish)

Kwiatkowska-Malina, J., 2018. Qualitative and quantitative soil organic matter estimation for sustainable soil management. Journal of Soils and Sediments 18, 2801-2812. https://doi.org/10.1007/s11368-0171891-1

Kuźnicki, F., Skłodowski, P., 1968. Przemiany substancji organicznej w niektórych typach gleb Polski. Roczniki Gleboznawcze - Soil Science Annual 19(1), 3-25. (in Polish)

Lehmann, J., Kleber, M., 2015. The contentious nature of soil organic matter. Nature 528 (7580), 60-68. https://doi.org/10.1038/nature16069

Licznar, M., Drozd, J., 1985. Wpływ erozji na właściwości związków próchnicznych w niektórych jednostkach systematycznych gleb. Roczniki Gleboznawcze - Soil Science Annual 36(3), 189-199. (in Polish with English summary)

Licznar, M., 1985. Właściwości gleb i kierunki ich ewolucji na terenach erodowanych Płaskowyżu Głubczyckiego. Wydawnictwo Akademii Rolniczej we Wrocławiu, Katedra Gleboznawstwa, 1-79. (in Polish)

Licznar, M., Drozd, J., Licznar, S.E., 1993. Skład ilościowy i jakościowy związków próchnicznych gleb deluwialnych Płaskowyżu Głubczyckiego. Zeszyty Problemowe Postępów Nauk Rolniczych 411, 139148. (in Polish)

Licznar, S.E., Łabaz, B., Licznar, M., 2004. Zawartość mikroelementów w czarnych ziemiach wrocławskich. Zeszyty Problemowe Postępów Nauk Rolniczych 502(1), 223-228. (in Polish)

Łabaz, B., 2007. Skład frakcyjny próchnicy czarnych ziem okolic Wrocławia. Roczniki Gleboznawcze - Soil Science Annual 58(1-2), 69-83. (in Polish with English summary)

Łabaz, B., 2010. Właściwości kwasów huminowych gleb czarnoziemnych występujących w rejonie Kłodzka. Woda-Środowisko-Obszary Wiejskie 10, 153-164. (in Polish with English summary)

Łabaz, B., Bogacz, A., Cybula, M., 2008. Właściwości substancji humusowych czarnych ziem w Parku Krajobrazowym Dolina Baryczy. Roczniki Gleboznawcze - Soil Science Annual 59(3), 175-184. (in Polish with English summary)

Łabaz, B., Musztyfaga, E., Waroszewski, J., Bogacz, A., Jezierski, P., Kabała, C., 2018. Landscape-related transformation and differentiation of Chernozems - Catenary approach in the Silesian Lowland, SW Poland. Catena 161, 63-76. https://doi.org/10.1016/ j.catena.2017.10.003

Łakomiec, I., Kozakiewicz, A., 1970. Trwałość fulwianów i humianów w zależności od odczynu środowiska. Roczniki Gleboznawcze - Soil Science Annual 21(1), 51-68. (in Polish with English summary)

Mucha, W., 1961. Z badań nad kwasami huminowymi. Roczniki Gleboznawcze - Soil Science Annual 10(suppl.), 1-3. (in Polish)
Musierowicz, A., Brogowski, Z., Skorupska, T., 1960. Materiały do poznania związków organicznych gleb polski. Roczniki Gleboznawcze - Soil Science Annual 10(1), 91-101. (in Polish)

Myneni, S.C., 2019. Chemistry of natural organic matter - The next step: Commentary on a humic substances debate. Journal of Environmental Quality 48(2), 233-235. https://doi.org/10.2134/jeq2019.02.0002c

Olk, D.C., Bloom, P.R., De Nobili, M., Chen, Y., McKnight, D.M., Wells, M.J.M., Weber, J., 2019. Using humic fractions to understand natural organic matter processes in soil and water: Selected studies and applications. Journal of Environmental Quality 48(6), 1633-1643. https://doi. org/10.2134/jeq2019.03.0100

Ohno, T., Hess, N.J., Qafoku, N.P., 2019. Current understanding of the use of alkaline extractions of soils to investigate soil organic matter and environmental processes. Journal of Environmental Quality 48(6), 1561-1564. https://doi.org/10.2134/jeq2019.08.0292

Piccolo, A., 2002. The supramolecular structure of humic substances: a novel understanding of humus chemistry and implications in soil science. Advances in agronomy 75, 57-134. https://doi.org/10.1016/ s0065-2113(02)75003-7

Pietrzykowski, M., Chodak, M., 2014. Near infrared spectroscopy - a tool for chemical properties and organic matter assessment of afforested mine soils. Ecological engineering 62,115-122. https://doi.org/10.1016/ j.ecoleng.2013.10.025

Ponomariewa, V.V., Płotnikowa, T.A., 1980. Humus i proces glebotwórczy. Metody i wyniki badań 1-220. (in Russian)

Schnitzer, M., 1978. Humic substances: Chemistry and reactions. [In:] Schnitzer, M., Khan, S.U., (Eds.), Soil organic matter. Elsevier, Amsterdam, 1-64.

Schnitzer, M., Monreal, Q.M., 2011. Quo vadis soil organic matter research? A biological link to the chemistry of humification. Advances in agronomy 113, 143-217. https://doi.org/10.1016/B978-0-12-3864734.00008-7

Skłodowski, P., 1986. Przemiany materii organicznej w glebach rdzawych i brunatnych kwaśnych. Roczniki Gleboznawcze - Soil Science Annual 37, 127-137. (in Polish with English summary)

Stevenson, F.J., 1994. Humus chemistry: Genesis, composition, reactions. John Wiley \& Sons Hoboken.

Strouhalova, B., Ertlen, D., Šefrna, L., Novák, T.J., Virágh, K., Schwartz, D., 2019. Assessing the vegetation history of European chernozems through qualitative near infrared spectroscopy. Quaternaire 30(3), 227-241. https://doi.org/10.4000/quaternaire.12101

Swift, R.S., 1996. Organic matter characterization. [In:] Sparks, D., Page, A.L., Sumner, M.E., (Eds.), Methods of soil analysis: Part 3 Chemical methods. Soil Science Society of America, American Society of Agronomy, 1011-1069.

Systematyka gleb Polski, 2019. Polskie Towarzystwo Gleboznawcze, Komisja Genezy Klasyfikacji i Kartografii Gleb. Wydawnictwo Uniwersytetu Przyrodniczego we Wrocławiu, Polskie Towarzystwo Gleboznawcze, Wrocław-Warszawa.

Tiurin, I.V., 1951. K mietodikie analiza dla srawnitielnogo izuczenia sostawa poczwiennogo gumusa. Trudy Poczw. Inst. AN SSSR 38, 1-250.

Trendel, J.M., Schaeffer, P., Adam, P., Ertlen, D., Schwartz, D., 2010. Molecular characterisation of soil surface horizons with different vegetation in the Vosges Massif (France). Organic Geochemistry 41(9), 1036-1039. https://doi.org/10.1016/j.orggeochem.2010.04.014

Turski, R., 1964. The influence of erosion on the organic matter compounds in the brown soils and chernozems of the Lublin Upland. Roczniki Gleboznawcze - Soil Science Annual 14, 325-352. (in Polish)

Turski, R., 1971. Substancja organiczna gleb terenów erodowanych. Soil Science Annual - Roczniki Gleboznawcze 22(1), 19-57. (in Polish)

Uggla, H., Ferczynska-Uggla, Z., Rog, Z., Wojciak, H., 1978. Z badań nad próchnicą leśną gleb bielicoziemnych w falistym mikrokrajobrazie pojezierza Olsztyńskiego. Roczniki Gleboznawcze - Soil Science Annual 29(2), 13-29. (in Polish) 
Waksman, S.A., 1925. What is humus? Proceedings of the National Academy of Sciences of the United States of America 11(8), 463-468.

Wasak, K., Drewnik, M., 2016. Properties of humus horizons of soils developed in the lower montane belt in the Tatra Mountains. Polish Journal of Soil Science 45(1), 57-68. https://doi.org/10.17951/pjss.2012.45.1.57

Weber, J., Chen, Y., Jamroz, E., Miano, T., 2018. Preface: Humic substances in the environment. Journal of Soils and Sediments 18(8), 2665-2667. https://doi.org/10.1007/s11368-018-2052-x

Weber, J., Jamroz, E., Kocowicz, A., Dębicka, M., Ukalska-Jaruga, A., Mielnik, L., Bejger, R., Jerzykiewicz, M., Bekier, J., and Ćwieląg-Piasecka, I., 2020. Isolation of the humin fraction from soil: preliminary comments, EGU General Assembly 2020, Online, 4-8 May 2020, EGU20203110, https://doi.org/10.5194/egusphere-egu2020-3110
Wells, M.J., 2019. Supramolecular answers to the organic matter controversy. Journal of Environmental Quality 48(6), 1644-1651. https://doi. org/10.2134/jeq2019.02.0089

Wilk, K., 1963. Porównanie polskiej i radzieckiej metody oznaczania składu próchnicy w glebach o różnym stanie kultury. Roczniki Gleboznawcze - Soil Science Annual 13 (suppl.), 181-185. (in Polish)

Wilk, K., 1971. Ważniejsze badania nad próchnica gleb Polski. Roczniki Gleboznawcze - Soil Science Annual 22(2), 61-68. (in Polish)

Wilk, K., Nowak, W., 1977. Skład frakcyjny związków próchnicznych niektórych typów gleb uprawnych. Roczniki Gleboznawcze - Soil Science Annual 23(2), 33-47. (in Polish)

\author{
Słowa kluczowe \\ Próchnica glebowa \\ Frakcjonowanie \\ Ekstrakcja alkaliczna \\ Czarnoziemy \\ Czarne ziemie
}

\section{Porównanie metod ekstrakcji sekwencyjnej i składu frakcyjnego związków próchnicznych w czarnoziemach i czarnych ziemiach Polski}

\section{Streszczenie}

Badania materii organicznej zawsze stanowiły ważny element charakterystyki środowiska glebowego. Poważne wyzwanie metodyczne wynika z powinowactwa substancji próchnicznych do frakcji mineralnej gleby, co wymusza stosowanie skomplikowanych procedur ekstrakcyjnych. Badacze podejmują próby wyodrębniania związków próchnicznych za pomocą ekstrakcji alkalicznej i kwaśnej, przy użyciu m.in. wodorotlenku sodu, pirofosforanu sodu i kwasu siarkowego. Niestety, zastosowanie różnych odczynników, w różnych kombinacjach i stężeniach rodzi wątpliwości co do porównywalności wyników uzyskanych różnymi metodami frakcjonowania. Celem niniejszej pracy przeglądowej jest analiza najważniejszych stosowanych w Polsce metod frakcjonowania związków humusowych (według Tiurina, Kononowej i Bielczikowej, Boratyńskiego i Wilka oraz Duchaufoura i Jacquina) i składu próchnicy ustalonego z wykorzystaniem tych metod, na podstawie opublikowanych wyników analiz gleb czarnoziemnych z różnych regionów Polski. Analiza potwierdziła, że metody są trudno lub nieporównywalne pod względem chemicznym, ze względu na odmienne warunki ekstrakcji na poszczególnych jej etapach. Jednak przyjęcie za podstawę porównania deklarowanej mobilności/siły związania z fazą mineralną gleby, wskazuje na relatywnie największe podobieństwo metod Tiurina i Boratyńskiego-Wilka. Generalnie, wszystkie metody frakcjonowania wykazują dominujący udział związków humusowych słabo związanych (mobilnych) oraz średnio-silnie związanych z nie-krzemianowymi komponentami gleby związków humusowych (pomijając znaczny udział substancji nieulegających alkalicznej ekstrakcji zwanych niekiedy huminami). Jeśli metody frakcjonowania próchnicy miałyby być nadal stosowane, niezbędne jest uznanie jednej procedury jako standardowej, gdyż jest to warunkiem wiarygodnej porównywalności wyników badań nad próchnicą różnych gleb, prowadzonych w różnych laboratoriach. Po przeanalizowaniu wszystkich wieloetapowych metod ekstrakcji próchnicy, które zakładają stosowanie odmiennych odczynników w różnych stężeniach wydaje się, że najpełniejsze wyniki daje metoda Tiurina. Autorzy sugerują jednak, że bardziej zaawansowane badania dotyczące m.in. składu czy struktury uzyskanych substancji humusowych mogą wymagać wdrażania metod nieinwazyjnych. 